\title{
Discourse Markers in Narrative Essays: A Case Study of Jordanian High School EFL Learners
}

\author{
Ghaleb Rabab'ah* \\ Department of Foreign Languages, University of Sharjah, United Arab Emirates \\ Ameena Ma'touq, Sharif Alghazo \\ Department of English Language and Literature, The University of Jordan, Jordan
}

Received on: 27-9-2020

Accepted on: 28-12-2020

\begin{abstract}
This study explores the use and functions of discourse markers (DMs) in the narrative essays of 85 Jordanian high school students adopting Frasers's (2006) framework. The results show that the most frequently used DMs were elaborative (55.1\%), followed by temporal (31.4\%), inferential (9.3\%) and contrastive (4\%) respectively. Regarding the functions of DMs, the results reveal that the participants employed elaborative markers to express addition of information, temporal markers to sequence the events, inferential markers to introduce reasons or results and contrastive markers to express contrast. The results also indicate that the most commonly used DMs were and (97.9\%), but (90.9\%), and because (76\%). The high occurrence of some DMs may be considered to be a strategy adopted by learners to avoid using unknown DMs. In addition, the results showcase that a number of factors may have influenced the use of DMs such as literal translation, lack of knowledge of some DMs, and overgeneralization. The study recommends that textbooks used to teach English in schools should incorporate more attention to DMs, particularly from a functional perspective.
\end{abstract}

Keywords: Discourse Markers, Discourse Competence, Writing, Jordanian EFL Learners.

\section{Introduction}

Successful communication in the second language (L2) requires the development of communicative competence (Hymes 1972). Savignon (1991) defined communicative competence as "the ability of language learners to interact with other speakers, to make meaning, as distinct from the ability to perform on discrete-point tests of grammatical knowledge" (264). Early theorizations in language learning and teaching showed that the development of grammatical forms and structures alone would allow individuals to communicate effectively in the $\mathrm{L} 2$, hence a complete focus on the teaching of grammatical rules to the exclusion of pronunciation and lexis. However, other theories of language learning posited that, as Hymes $(1972,63)$ argues, "[t]here are several sectors of communicative competence, of which the grammatical is one." Savignon (1991) also contends that successful communication requires language users to understand the sociocultural context of language use. Successful communication, therefore, requires that,

๑ 2022 JJMLL Publishers/Yarmouk University. All Rights Reserved,

${ }^{*}$ Doi: https://doi.org/ 10.47012/jjmll.14.1.11

* Corresponding Author: ghalebrababah@gmail.com 
Rabab'ah, Ma'touq, Alghazo

in addition to knowledge of language, both speakers and hearers understand non-verbal cues, such as facial expressions and, more importantly, the speaker's implicature.

When we turn to writing in the L2, the value of successful communication in writing is no less valid. Individuals should be able to write cohesively and coherently to achieve the functional purpose of writing. As part of cohesion, the use of discourse markers (DMs) is a linchpin. DMs-which are, by some, labelled discourse particles and discourse connectives and, by others, pragmatic markers and pragmatic connectives - are defined by Fraser (2009) as expressions which relate to the discourse structure but not the propositional content; that is, they do not add to the meaning. According to Fraser (2009), this definition implies two conditions for qualifying DMs: They function as connectives, and they are non-truth conditionals. However, DMs, as Fraser (2009) argues, signal some aspects of the message conveyed. DMs are used for a number of functions including connecting and organizing segments of the discourse. Thus, the proper use of DMs in both spoken and written discourse is an essential aspect of communicative competence. In her discussion of academic writing, Al-khazraji (2019) argues that the correct use of DMs is very important for L2 learners. Essentially, DMs contribute to the discourse as they are the building blocks which facilitate the textual flow for the reader.

\section{Theoretical background and literature review}

Research on DMs has produced three main approaches. The first is the discourse coherence model which was presented by Schiffrin (1987) who conceived of DMs as connectors of the different segments of discourse, hence the creation of coherence. This approach was mainly concerned with DMs in spoken discourse which is evident in Schiffrin's (1987) definition of DMs as successively dependent language elements. The second approach was developed by Fraser (1990) who studied DMs from a grammaticalpragmatic perspective. Fraser (2009) suggests that DMs are lexical expressions that function as connectors and classifies English DMs into three functional classes: contrastive (e.g., but), elaborative (e.g., and), and inferential (e.g., so). The third approach was proposed by Maschler (1994) who adopts a functional interactional perspective suggesting that there is a strong tie between the qualification of DMs and participants' cognitive processes.

There is consensus among scholars and researchers that DMs play a major role in the production of cohesive and coherent texts, as noted earlier. This agreement was a result of the research that examined the use of DMs in academic writing in both native and non-native English productions and the impact of language proficiency on their language production. For example, Martinez (2004) examined the use of DMs in the writings of 78 Spanish undergraduate students and found that student participants use a variety of DMs, with elaborative markers being the most frequent. The results also showed that there is a strong correlation between scores of the composition and the use of DMs: the larger the use, the higher the score. A similar link between learners' proficiency levels and the use of DMs was found in Šimčikaite (2012) who showed that Lithuanian learners of high proficiency levels were more likely to employ DMs in their essay writing. 


\section{Discourse Markers in Narrative Essays: A Case Study of Jordanian}

High School EFL Learners

Teaching English to 20 Indian English as a foreign language (EFL) students to find the effect of the use of DMs on coherence and cohesion, Chetia (2013) divided participants into three groups based on the language of instruction: English medium, urban vernacular medium, and rural vernacular medium. The results showed that the use of DMs played a major role in the production of cohesive and coherent texts in English. In addition, the results indicated that the group that was taught using an urban vernacular used the highest number of DMs in their texts.

In another study, the use of DMs by 127 Jordanian EFL learners was examined by Ali and Mahadin (2016) to see the effect of students' proficiency level. The results showed that advanced learners made more use of DMs than intermediate learners. Moreover, the results indicated that the most frequent class of DMs was elaborative, with $47.1 \%$, followed by inferential markers, with $17.8 \%$, temporal markers, with $12.9 \%$, contrastive markers, with $11.1 \%$, and spoken markers, with $11.0 \%$, respectively.

In a recent study, Jegarlooei and Allami (2018) examined the pragmatic competence and the use of DMs by Iranian EFL learners, their teachers and American native speakers as indicators of politeness with regard to gender and proficiency. The researchers used open discourse role-play tasks, a selfassessment report of English competence as well as seven scenarios to collect the data from Iranian L2 learners, EFL teachers and American native speakers. The results revealed that native English speakers significantly surpassed EFL teachers and L2 learners in employing DMs and that instruction and proficiency levels played a significant role in L2 learners' use of DMs. The results also showed that the female Iranian L2 learners outperformed their male counterparts in using the DMs of approximators, modals, and passives implying that the female language learners minimize a face-threatening act and the tone of an utterance significantly.

The use of DMs in written essays was also the main concern of some researchers (e.g., Sohaya, 2018; Wahid et al., 2020), who did not look at the effect of proficiency level on the use of DMs or coherence and cohesion. Sohaya (2018) investigated the types of DMs in texts written by 200 senior high school students and found that seven types were used in the texts, namely, contrastive markers, elaborative markers, inferential markers, reason markers, conclusive markers, exemplifier markers and sequential markers. It was also found that sequential markers were the first dominant type of DMs. Similarly, Wahid, et at. (2020) examined the use of DMs in 96 descriptive essays used by junior high school Indonesian students and found that distance DMs were the most frequently used, followed by elaborative, temporal, contrast, comparison, reason, causal, and conclusion. The results also showed that the students' use of DMs was inappropriate because of their lack of knowledge.

Some researchers were interested in examining the appropriateness and correctness of EFL learners' use of DMs. Asassfeh, Alshboul and Alshaboul (2013), for instance, examined the use of DMs in 146 essays written by Jordanian undergraduate EFL students. Quantitative and qualitative analyses revealed the students used DMs redundantly; that is, they used synonymous DMs in the same segment. In addition, variety in the use of DMs was rare; they overused some DMs, such as because and so, and they underused other DMs such as thus and as a result. The results also showed that some DMs were syntactically and semantically misused by the students. In the same vein, Al-Khazraji (2019) investigated English as a 
Rabab'ah, Ma'touq, Alghazo

second language (ESL) students' knowledge of DMs in essay writing. Sixty essays were collected from intermediate ESL students in Grade 9 at a school in Dubai; nine of which were analyzed. The findings were categorized into three parts: 'misused discourse markers', 'overused discourse markers', and 'advanced used discourse markers'. The results showed that ESL students use several types of DMs, such as inferential, elaborative, causative, and contrastive markers. Some of them are used correctly, while others are not. It was also found that the more appropriately DMs are used, the better the quality of students' writing.

Another area of research that attracted the attention of some researchers is the use of DMs by EFL teachers. For example, Rabab'ah (2015a) looked at classroom discourse and studied three types of DMs (additive, adversative and causative) in the classroom interactions of 40 Saudi EFL teachers. The study found that the three types of DMs were found in the participants' classroom interactions. However, the additive DMs were more frequent than other types. As for the functions of DMs, the results showed that the teachers used DMs for many functions: addition, contrast, denial and cancellation. Nevertheless, some uses of DMs were erroneous and misused.

DMs were also studied in written business communication. For instance, in the discourse of professional writing, particularly email writing, Faghih and Mousaee (2015) studied the use of DMs in 60

INTERPOL electronic messages produced by native and non-native English-speaking police officers. The data were analyzed using SPSS following Fraser's (2006) framework. The findings showed no significant differences in the use of DMs by both groups of writers except in the use of inferential DMs which were more frequent in the writings of non-native English writers.

Based on the foregoing, existing research on the use of DMs in the Jordanian context is mostly related to tertiary education and - to the best of the researchers' knowledge — no one study examined the use of DMs in the writings of Jordanian EFL high school students. In an attempt to fill this gap, this study concerns itself with an exploration of how DMs are used in the writings of Jordanian EFL students. More specifically, it aims to answer the following research questions:

1. What are the most common functional classes of DMs in the writings of Jordanian EFL students in narrative essays?

2. What are the functions of DMs used by Jordanian EFL students in writing narrative essays?

\section{Methodology}

\subsection{Participants}

Convenience sampling was used in the present study to select participants who were 85 high school students at Ma'an secondary school for girls, Jordan. Their ages ranged between 17 and 18 years old. They were all females. All participants were native Jordanian Arabic speakers. They had been studying English for over 11 years. None of the participants had stayed in an English-speaking country for more than three months, or had a parent who is a native speaker of English. Furthermore, they all had studied at Jordanian public schools, and had been taught English by native speakers of Arabic. 
Discourse Markers in Narrative Essays: A Case Study of Jordanian

High School EFL Learners

\subsection{Corpus}

The data were collected using a writing task in which the student participants were asked to write a narrative essay on one of two topics taken from English textbooks. They were asked to write a narrative essay about either a dream they had or a memorable trip. It should be noted that the selected topics were familiar to students. The amount of time given to students was 45 minutes. All students participated and a total of 85 compositions were collected. Some of the students wrote about a dream and some wrote about a memorable trip. The compositions were thoroughly analyzed for DMs using Fraser's (2009) framework. However, it is worth mentioning that the topic is not considered a variable in the present research.

\subsection{Framework of data analysis}

In order to analyze the data, the study adopted Fraser's (2006) taxonomy because it is one of the most comprehensive taxonomies for the classification of DMs and highly relevant to academic written discourse. It is worth mentioning that Fraser's (2009) updated taxonomy does not include temporal DMs because they do not indicate a semantic relation between discourse segments. However, many studies, including this one, follow Fraser's (2006) earlier categorization because the focus of these studies is not only on the sematic content of the segments but also on the discourse functions of DMs. Hence, this study relied on Fraser's (2006) taxonomy. Table 1 below presents the taxonomy which incorporates four functional classes of contrastive, elaborative, inferential, and temporal markers. The boldfaced DMs are called by Fraser (2006) "the primary DM of the class ... with the others being ordinary members" (p. 196).

Table 1: Fraser's taxonomy of DMs (2006, pp. 196-197).

\begin{tabular}{ll}
\hline Category & \multicolumn{1}{c}{ DMs } \\
\hline Contrastive & $\begin{array}{l}\text { but, alternatively, although, contrariwise, contrary to expectations, conversely, despite } \\
\text { (this/that), even so, however, in spite of (this/that), in comparison (with this/that), in } \\
\text { contrast (to this/that), instead (of this/that), nevertheless, nonetheless, (this/that point), } \\
\text { notwithstanding, on the other hand, on the contrary, rather (than this/that), regardless } \\
\text { (of this/that), still, though, whereas, yet }\end{array}$ \\
\hline Elaborative & $\begin{array}{l}\text { and, above all, also, alternatively, analogously, besides, by the same token, } \\
\text { correspondingly, equally, for example, for instance, further(more), in addition, in other } \\
\text { words, in particular, likewise, more accurately, more importantly, more precisely, more } \\
\text { to the point, moreover, on that basis, on top of it all, or, otherwise, rather, similarly, } \\
\text { that is (to say) }\end{array}$ \\
& $\begin{array}{l}\text { so, after all, all things considered, as a conclusion, as a consequence (of this/that), as a } \\
\text { result (of this/that), because (of this/that), consequently, for this/that reason, hence, it } \\
\text { follows that, accordingly, in this/that/any case, on this/that condition, on these/those } \\
\text { grounds, then, therefore, thus }\end{array}$ \\
\hline Temporal & $\begin{array}{l}\text { then, after, as soon as, before, eventually, finally, first, immediately afterwards, } \\
\text { meantime, meanwhile, originally, second, subsequently, when }\end{array}$ \\
\hline
\end{tabular}

\section{Results}

4. 1 Functional classes of DMs in Jordanian EFL students' writings

In order to answer the first research question concerning the most common functional classes of DMs in the writings of Jordanian EFL students, 85 essays written by the participants were read and analyzed. A total of 537 DMs was found, coded, and classified under the four classes of Fraser's (2006) 
Rabab'ah, Ma'touq, Alghazo

taxonomy: elaborative, temporal, inferential, and contrastive. The data in Table 2 below summarize the classes of DMs which were used by the participants, along with their frequencies and percentages of occurrence.

Table 2: Frequencies and percentages of DMs in the participants' writings

\begin{tabular}{lcc}
\hline Classes of discourse markers & Frequency & Percentage \\
\hline Elaborative markers & 290 & 97.9 \\
And & 3 & 1.0 \\
for example & 3 & 1.0 \\
Also & $\mathbf{2 9 6}$ & $\mathbf{5 5 . 1}$ \\
Total & & \\
\hline Temporal markers & 41 & 24.2 \\
Then & 40 & 23.6 \\
After & 34 & 20.1 \\
Finally & 25 & 14.7 \\
When & 20 & 11.8 \\
First & 9 & 5.3 \\
Before & $\mathbf{1 6 9}$ & $\mathbf{3 1 . 4}$ \\
Total & & \\
\hline Inferential markers & 38 & 76 \\
Because & 32 & 24 \\
So & 12 & $\mathbf{9 . 3}$ \\
Total & $\mathbf{5 0}$ & \\
\hline Contrastive markers & & 90.9 \\
Although & 20 & 9.0 \\
Total & 2 & $\mathbf{4 . 0}$ \\
\hline
\end{tabular}

As shown in Table 2 above, the most frequent DMs in the writings of the participants were elaborative $(55,1 \%)$ followed by temporal (31,4\%), inferential $(9,3 \%)$ and contrastive $(4,0 \%)$, respectively. The analysis also confirmed Fraser's (2006) claim that 'and', 'but', 'then' and 'because' are primary DMs as they were the most frequent DMs in each class.

\subsection{Functions of DMs used by Jordanian EFL students}

The second research question asked about the functions of DMs as used by the Jordanian EFL students. The analysis showed that the DMs were employed by the participants to fulfil different functions as follows:

\section{Elaborative Markers}

As noted above, elaborative markers were the most frequent DMs in the writings of the Jordanian EFL learners. The DMs in this class are typically used to indicate a parallel relation between discourse segments. As is also shown above, 'and', 'also' and 'for example' were, respectively, the most commonly used. Here, we analyze the functions of these DMs as used in the participants' compositions. It should be noted that because the focus of the study is on the use of DMs, grammatical errors (e.g., I like to see stars), spelling errors (e.g., by instead of buy) and inappropriate lexical choice (e.g., the use of watch instead of see) were not considered and thus corrected in the authentic examples presented in this section. The following are examples of language segments where elaborative DMs were used. 


\section{Discourse Markers in Narrative Essays: A Case Study of Jordanian}

High School EFL Learners

1. We eat ice cream and drink apple juice.

2. I $\underline{\text { and }}$ my family go in a trip to Aqaba.

3. My sister $\underline{\text { and }}$ her husband are waiting in airport.

4. We $\underline{\text { also }}$ found many of Japanese dress, it is very beautiful and nice.

5...... and we can go shopping we can $\underline{\text { also }}$ go to the zoo to see the animals.

6. Finally, we went to Ma'an after hard and interesting trip.

7. The weather was nice in the morning $\underline{\text { and }}$ very cold in the night so I wore a jacket.

8. Went to the zoo and I watch a danger $\underline{\text { and }}$ a beautiful animal.

9. I go to the sea and I go around by boat and I go to the restaurant, I go to the shopping bought seat and clothes and games.

10. We watched animals, for example: lion, dog, tiger.

11. You can do a lot of activities at Aqaba, for example you can visit the castle, do scuba diving, go shopping and lots of activities.

As can be observed from Examples (1-6) above, the DMs 'and' and 'also' were used to connect two similar ideas and to indicate the addition of new information. In Examples (7 and 8), 'and' was misused. Because of the conflict that exists between the two ideas, 'but' is more appropriate. For example, in relation to Example (6), the intended meaning is that 'although the trip was tiring, it was interesting'. Because there is a conflict between the two ideas presented in the discourse, 'but' as an adversative DM is more appropriate. However, such errors may be due to word-for-word translation from the participants' first language (L1), Arabic, to English. In Example (9), even though the meaning of the sentence is comprehensible, the high occurrence of elaborative markers, notably 'and', was considered stylistically inappropriate because such use might lead to monotonous writing caused by the repetition of the same marker. In Examples (10 and 11), 'for example' was correctly used to clarify the statement by giving examples. In (10), lions, dogs, tigers were examples given to clarify the meaning of the sentence.

This analysis clearly shows that elaborative markers were employed to link equal propositions and that, in the majority of cases, the use of elaborative markers was correct. On the other hand, it could be assumed that the overuse of 'and' was the result of intralingual contact, particularly processes of overgeneralization. Thus, the participants used a limited set of DMs and generalized their use to other contexts. In addition, word-for-word literal translation may have contributed greatly to the inappropriate use of DMs.

\section{Temporal Markers}

Temporal markers had the second highest rank of the DMs used by the participants, with 169 occurrences and a percentage of $31.4 \%$. Temporal markers include words such as 'then', 'after', 'before', 'as soon as', 'afterwards', among others. These words indicate a temporal relation between discourse segments. The following are examples taken from the data: 
Rabab'ah, Ma'touq, Alghazo

1. First, we went to the restaurant and we ate Mansaf, then we went to the Red Sea.

2. Before we leave, we back to sea.

3. Before we back home to Ma'an my dad take us to the marine museum.

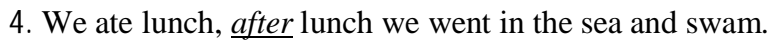

5. When my birthday came I was in Turkey.

6. When I was in the plane I felt interesting

7. When I arrived the weather is very cold.

8. Finally, I advise you to travel to Turkey because it amazing country

In Examples (1-5), all the underlined words are temporal markers which were correctly used to sequence the order of events. For example, in Sentence (1), 'first' and 'then' were correctly used: 'first' was used to indicate that the action happened before other actions, and 'then' was used to refer to what happened next. In Sentences (2 and 3), 'before' was employed to indicate that the second action occurred before the first action, while 'after' was employed in Sentence (4) to express that a particular event happened after another. Sentences (5-7) show that 'when' was used to indicate the time when a particular action occurred. In (9), 'finally' was used to refer to an event that happened at the end.

Inferential Markers

Inferential markers consist of DMs such as 'hence', 'after all', 'consequently', among others. Their use indicates that the second part of the sentence is realized as a conclusion for the first part. This class accounted for 9.3\%. The used inferential markers were 'because' and 'so'. Here are some illustrative examples from the data:

1. My sister and I went shopping because we bought something.

2. The scene was great and unforgettable for me, $\underline{\text { because }}$ I like to see the stars in the night.

3. We went to the red sea, because my sister wants to see the colorful marine animals.

4. We went home because to take rest.

5. The weather was nice in the morning and very cold in the night $\underline{s o}$ I wore a jacket

6. $\underline{S O}$ I advise you to visit this and enjoy it.

7. We went shopping $\underline{s o}$ by clothes.

8. We went to the cinema $\underline{s} \underline{0}$ watch film.

9. $\underline{S O}$ that going to the restaurant to have delicious food.

10. $\underline{S o}$ that enter marine museum watching many fish and shark. 


\section{Discourse Markers in Narrative Essays: A Case Study of Jordanian \\ High School EFL Learners}

In all the above-mentioned examples, the use of the inferential markers was, in the main, correct. In Examples (1-4), 'because' was used to introduce reasons. The discourse marker 'so' was used to indicate that the second part of the sentence is realized as a result or a conclusion of the first part. However, in relation to Sentences (7-10), 'so' was mistakenly used to express a reason; a more appropriate DM would have been 'in order to', or 'because'.

Based on this, it may be argued that different factors influenced the production of inappropriate markers: One possibility is that some L2 learners of English assume that DMs in English and Arabic are the same, so whenever they need an unfamiliar DM, they rely on literal translation from Arabic. Another reason could be the teachers' negligence of DMs in EFL classrooms.

\section{Contrastive Markers}

Contrastive markers refer to DMs which express a contrast between two segments. This class accounted for $4 \%$ of the DMs used by the participants. The used markers within this group were 'but' and 'although' as illustrated below:

1. Although we feel tired $\underline{b u t}$ this trip very wonderful and cool.

2. We was very tired but was very interesting day.

3. We will vary tired $\underline{\text { but }}$ we will vary happy.

4. It was very simple thing $\underline{b u t}$ it makes us happy.

5. ...but short dream $\underline{\text { but }}$ beautiful.

In Sentence (1), 'although' and 'but' were correctly used together to introduce two contrasting ideas. Similarly, in Sentences (2-5), 'but' was used to link ideas that were contrasted in meaning.

\section{Discussion}

The results of this study revealed that the four major classes of DMs in Fraser's (2006) taxonomy were used in the Jordanian EFL students' writings. As noted earlier, the most frequent DMs were elaborative, temporal, inferential, and contrastive. Another important finding was that there was a high use of some elaborative markers, including 'for example', 'also', and, most notably, 'and'. This high reliance on 'and' could be attributed to the fact that learners depend on the most common terms which seem to have been mastered before others to replace the unknown DMs. This finding is in line with previous studies, particularly that of Asassfeh, Alshboul and Alshaboul (2013) who found that 'and' was the most common in the essays written by Jordanian subjects.

On the other hand, a wider range of temporal DMs were employed by the participants to relate the segments to the preceding segments. As shown above, 'then', 'after', and 'finally' were overused by the participants. However, the wide range of temporal DMs used in the corpus of the present study might be attributed to the writing topics, which required narration of events which might have directed the participants to use these particular types of DMs. The over use of temporal DMs as shown in the present 
Rabab'ah, Ma'touq, Alghazo

study is in agreement with Asassfeh, Alshboul and Alshaboul (2013) who pointed out that temporal markers were used more than other types of DMs, and they attributed it to the explicit instruction given by teachers to use temporal DMs.

Contrastive DMs were the least used by the participants. They were used to show contrast between two propositions and this accounted for $4 \%$. As presented in Table 2 above, within this class, 'but' accounted for $90.9 \%$ of the overall percentage of contrastive markers. This might have resulted from the high exposure to this marker at an early stage of English language learning. This finding accords with that of Ali and Mahadin (2016) and Martinez (2004) who found that 'but' was overused by the participants. In addition, the study has revealed that the participants overused some inferential markers, notably 'because' to compensate for the lack of linguistic knowledge. This result is similar to those of Ali and Mahadin (2016), Asassfeh, Alshboul and Alshaboul (2013) who reported that 'because' was overused by the participants in their study. This also lends support to Al-Khazraji (2019) who found that ESL students use several types of DMs, such as inferential, elaborative, causative, and contrastive markers. The overuse of 'because' as a causative DM could be attributed to its popularity among students and teachers.

This apparent variation in the use of DMs by the students-i.e., overuse of some (e.g., 'and', 'because', and 'but' and complete absence of others (e.g., 'despite', 'therefore', and 'afterwards')—shows that the mastery of English DMs is a challenge to Arabic-speaking learners of English which calls for awareness and instruction programs. This finding lends support to Al-khazraji (2019) who concluded that "the efficient utilization of Discourse Markers is an essential element and the shortage of it is seen as a novice error among the second language writers" (p. 559). This is also in line with Jegarlooei and Allami (2018) who found that native speakers significantly surpassed EFL teachers and L2 learners in employing DMs and that instruction and proficiency level played a significant role in L2 learners' use of DMs. Therefore, teachers must raise their students' awareness of the value of properly using DMs for cohesion and coherence and of the effect of misusing DMs on both oral and written communication. Indeed, DMs are the tools that connect segments of discourse together. At the instruction level, teachers and materials writers should incorporate DMs into their syllabuses by varying the tasks that pertain to the appropriate use of DMs. Writing as an expressive skill must also be emphasized in English language teaching curricula in a fashion that allocates more time to the discourse structure of texts and the role of DMs in the construction of the text.

\section{Conclusion}

This study has examined the use of English DMs in the writings of high school Jordanian students, by means of both quantitative and qualitative analyses of the students' compositions based on Fraser's (2006) taxonomy. Although the study concerned itself with exploring the use of DMs by high school students, the findings may be applicable to other levels of students in the Jordanian context, and probably in the wider EFL context. As noted earlier, the findings of this study accord with findings of other studies in Jordan and other EFL contexts (see Ali \& Mahadin 2016; Asassfeh, Alshboul \& Alshaboul 2013; 
Discourse Markers in Narrative Essays: A Case Study of Jordanian

High School EFL Learners

Martinez 2004; among others). The findings confirmed that the use of DMs represents a challenge to many Jordanian EFL students which warrants intervention in EFL classrooms.

Fraser $(2006,196)$ states that "there are over 100 DMs in English." However, only 13 DMs were found in the productions of the participants. This result also calls for apprising students of the variety of DMs and of the significance of varying this use for more academic and target-like production of English. The 13 DMs were classified under the four main classes of elaborative, temporal, inferential, and contrastive. However, elaborative DMs were more frequently used by the participants. This use has been attributed to the nature of the narrative topics the students were required to write about. It is suggested that future research may examine the effect of both proficiency level and topic on Jordanian EFL learners' use and choice of DMs. As for the functions of DMs, the results have shown that some DMs were properly used for their functions while others were misused by the participants. For example, the participants employed elaborative markers to express addition of information, temporal markers to sequence their events, inferential markers to show results and reasons and contrastive markers to express contrast.

Within the elaborative class of DMs, 'and' was the most frequent, and among the inferential DMs, 'because'. This is in agreement with Fraser's (2006, 2009) proposition that 'and' and 'because' are the primary DMs in their respective classes. This apparent overuse of the primary DMs could be attributed to the high exposure to these markers. Some factors may have also influenced students' over-production of these markers, including overgeneralization and literal translation. The results have also revealed that some DMs (for example, 'therefore', 'as soon as', 'in comparison', and 'more importantly') need to be considered by EFL teachers and learners. Based on the results, it could be concluded that Jordanian high school students who participated in the study have not yet developed full competency in the use of English DMs.

\section{Implications}

The appropriate use of DMs is considered to be one of the most important prerequisites for effective and successful communication because it reflects an advanced linguistic level on the part of English language learners. On the other hand, the inappropriate use and/or the lack of DMs is disruptive because to the conveyance of the message on the part of L2 users. The findings showed that the most serious problems encountered by the students were the overuse of some DMs, insufficient use of other DMs, and recourse to literal translation. This result has some implications for English language teaching in EFL contexts. The study, therefore, calls for more attention to DMs in writing courses and other communication materials. Contextualization of language structures, and particularly DMs is a key to more target-like production of the L2. Exposing students to the target language input help EFL students to test their hypotheses about language and expand their knowledge to use the new target language items (e.g., discourse markers) to different contexts (Rabab'ah 2015b). It has the potential to help students to create form-function links. Moreover, raising awareness among students of the value of using DMs appropriately in creating natural texts would help students vary their use of DMs. Last, but by no means 


\section{Rabab'ah, Ma'touq, Alghazo}

least, the students should also become aware of the differences between their L1, Arabic, and the L2, English in respect of the use of DMs.

As for English language teachers, the study calls for more emphasis on DMs in language curricula and teaching materials. Teachers should raise students' awareness of the most difficult language structures, such as DMs, and prepare remedial work that targets the mistakes that EFL students make (Rabab'ah et al. 2016). EFL teachers should also vary their teaching strategies to incorporate more authentic and contextualized language tasks. Materials writers are also urged to give more space to DMs in their language textbooks on the basis of findings of research on second language acquisition. 
Discourse Markers in Narrative Essays: A Case Study of Jordanian High School EFL Learners

\section{استخدام علامات الخطاب (Discourse markers) في المقالات السردية: دراسة لحالة طلبة الثانوية العامة في الأردن في آلمات}

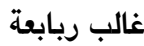

قسم اللفات الأجنبية، جامعة الثارقة، الإمارات العربية المتحدة

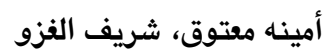

قسم اللفة الانجليزية وآدابها، الجامعة الأردنية، الأردن

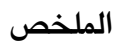

تبحث هذه الدراسة في استخدام علامات الخطاب ووظائفها في المقالات السردية لأربعة وثمانين طالباً من طلبة الثانوية

العامة الأردنيين باستحدام تصنيف فريزر (Fraser, 2006). وقد أظهرت النتائج أن أكثر علامات الخطاب استخداماً هي

العلامات التفصيلية (55.1\%) ثم الزمنية (31.4\%) ثم الاستنتاجية (9.3\%) ثم التفصيلية (4\%). أما بالنسبة لوظائف

علامات الخطاب، فقد بينت النتائج أن المشاركين في البحث استخدموا العلامات التفصيلية للتعبيرعن إضافة معلومات،

والعلامات الزمنية لتسلسل الأحداث والعلامات الاستنتاجية لتقديم أسباب أو نتائج، والعلامات التفضيلية للتعبير عن

المفاضلة. وقد أظهرت النتائج أيضاً أن أكثر علامات الخطاب استخداماً هو "و" (97.9\%) ثم "لكن" (90.9\%) ثم "لأن"

(76\%). إن الاستخدام العالي لبعض علامات الخطاب يمكن أن يكون استراتيجية يستخدمها الطلاب لتفادي استخدام علامات

خطاب غير معروفة لهم. كذلك، بينت النتائج أن هنالك عدداً من العوامل التي تؤثر في استخدام علامات الخطاب مثل الترجمة

الحرفية وقلة المعرفة ببعض علامات الخطاب والتعميه. وقد أوصت الدراسة بأن تثتمل الكتب التي تستخدم لتدريس اللفة

الإنجليزية على جانب من الاهتمام والتركيز على استخدام علامات الخطاب من الجانب الوظيفي.

الكلمات المفتاحية: علامات الخطاب، كفاية الخطاب، الكتابة، متعلمو اللفة اإلانجليزية كلفة أجنبية. 
Rabab'ah, Ma'touq, Alghazo

\section{References}

Ali, Eman and Radwan Mahadin. 2016. The Use of Discourse Markers in Written Discourse by Students of English at the University of Jordan. International Journal of Humanities and Social Science 6: 2335.

Al-khazraji, Asmaa. 2019. Analysis of Discourse Markers in Essays Writing in ESL Classroom. International Journal of Instruction 12: 559-572.

Asassfeh, Sahail, Sabri Alshboul, and Yousef Al-shaboul. 2013. Distribution and Appropriateness of Use of Logical Connectors in the Academic Writing of Jordanian English-major Undergraduates. Journal of Educational \& Psychological Sciences 14: 12-35.

Chetia, Barnali. 2013. Discourse Markers in Written English Texts in a Multilingual Setting: A Comparative Study of High School English in the Schools of Assam. Language in India 13: 40-70.

Faghih, Esmail and Akbar Mousaee. 2015. English Writing Skill in Terms of Discourse Markers in Interpol Electronic Messages Written by Non-native and Native Police Officers: A Comparative Study. Journal of Applied Linguistics and Language Research 2: 10-23.

Fraser, Bruce. 1990. An Approach to Discourse Markers. Journal of Pragmatics 14: 383-395.

Fraser, Bruce. 1999. What are Discourse Markers? Journal of Pragmatics 31: 931-953.

Fraser, Bruce. 2006. "Towards a Theory of Discourse Markers". In Approaches to discourse particles, ed. K. Fisher, 189-204. Oxford: Elsevier.

Fraser, Bruce. 2009. An Account of Discourse Markers. International Review of Pragmatics 1: 1-28.

Hymes, Dell. 1972. “On Communicative Competence”. In Sociolinguistics: Selected readings, ed. J. B. Pride and J. Holmes, 53-73. Harmondsworth, England: Penguin Books.

Jegarlooei, Seyyed and Hamid Allami. 2018. (Im)politeness Strategies and Use of Discourse Markers. Cogent Arts \& Humanities 5: 1-24.

Martinez, Ana. 2004. Discourse Markers in the Expository Writing of Spanish University Students. IBÉRICA 8: 63-80.

Maschler, Yael. 1994. Metalanguaging and Discourse Markers in Bilingual Conversation. Language in Society 23: 325-366.

Rabab'ah, Ghaleb. 2015a. An Analysis of Conjunctive Discourse Markers in the EFL Classroom: A Case Study of EFL Teachers in Saudi Arabia. International Journal of Innovation and Learning 17: $307-$ 325.

Rabab'ah, Ghaleb. 2015b. The Effect of Communication Strategy Training on the Development of EFL Learners' Strategic Competence and Oral Communicative Ability. Journal of Psycholinguistic Research 44: 625-651.

Rabab'ah, Ghaleb, Bayan Rababah and Nour Suleiman. 2016. Instant Messaging Language in Jordanian Female School Students' Writing. Teaching English with Technology 16: 116-142.

Savignon, Sandra. 1991. Communicative Language Teaching: The State of the Art. TESOL Quarterly 25 : 261-277.

Schiffrin, Deborah. 1987. Discourse Markers. Cambridge: Cambridge University Press. 


\section{Discourse Markers in Narrative Essays: A Case Study of Jordanian}

High School EFL Learners

Šimčikaite, Ale. 2012. Spoken Discourse Markers in Learner Academic Writing. Studies about Languages 20: 27-34.

Sohaya, E.M. 2018. English discourse markers used in the procedure text written by senior high school students. PhD diss., University of Muhammadiyah Sumatera Utara Medan Retrieved from: http://repositori.umsu.ac.id/xmlui/handle/123456789/3789

Wahid, Abdul, Imam Sunitno, Suyono Suyono, and Martutik Fsmartutik. 2020. Discourse marker in descriptive essays: A study on junior high school students. Journal for the Education of Gifted Young Scientists 8 (3): 1099-1111. 